\title{
Obsidian provenance studies in the far eastern and north- eastern regions of Russia and exchange networks in the prehistory of Northeast Asia: a review
}

\author{
Yaroslav V. Kuzmin \\ Sobolev Institute of Geology and Mineralogy, Siberian Branch of the Russian Academy of Sciences, Novosibirsk, RU \\ kuzmin@fulbrightmail.org; kuzmin_yv@igm.nsc.ru
}

\begin{abstract}
This overview is based on the results of 25+ years of provenance studies to identify the sources of high-quality volcanic glass (obsidian) in prehistoric cultural complexes of the far eastern and northeastern regions of Russia (Maritime Province, the Amur River basin, Sakhalin Island, the Kurile Islands, Kamchatka Peninsula, Chukotka region, the Kolyma River basin, and the High Arctic), as well as in adjacent parts of Northeast Asia (Hokkaido Island, the Korean Peninsula, and Manchuria). The extended networks of obsidian exchange in antiquity are reconstructed for the southern Russian Far East and Northeastern Siberia. A possible mechanism of long-distance obsidian exchange/ trade in Northeastern Siberia is suggested.
\end{abstract}

KEY WORDS - obsidian; provenance study; prehistoric exchange; far eastern Russia; Northeastern Siberia

\section{Študije provenience obsidiana na območju ruskega Daljnega Vzhoda in $v$ severovzhodni Rusiji ter mreže menjav v prazgodovini $v$ severovzhodni Aziji: pregled}

\begin{abstract}
IZVLEČEK - Pričujoča presoja je osnovana na rezultatih več kot 25 let študij provenience pri iskanju izvorov visoko kakovostnega vulkanskega stekla (obsidiana) v prazgodovinskih kulturnih kompleksih na ruskem Daljnem Vzhodu in v regijah severovzhodne Rusije (obmorske province, območje reke Amur, otok Sahalin, Kurilsko otočje, polotok Kamčatka, območje Čukotka, območje reke Kolime in Arktično višavje) kot tudi v sosednjih delih severovzhodne Azije (otok Hokkaido, Korejski polotok in Mančurija). Za območji južnega dela ruskega Daljnega Vzhoda in severovzhodno Sibirijo smo že rekonstruirali razširjeno mrežo menjave obsidiana v preteklosti. Predlagamo pa možne mehanizme menjav/ trgovine z obsidianom na daljše razdalje na območju severovzhodne Sibirije.
\end{abstract}

KLJUČNE BESEDE - obsidian; provenienca; prazgodovinska menjava; ruski Daljni Vzhod; severovzhodna Sibirija

\section{Introduction}

Research on the provenance of artefacts made of waterless volcanic glass (obsidian) began at the modern methodological level in the 1960s, first in the Mediterranean (Cann, Renfrew 1964) and afterwards in the Americas, Europe, East Africa, Oceania, and East and Southeast Asia (see bibliographies: Skinner, Tremaine 1993; Pollmann 1999). The success of obsidian source studies in the 1970s to 2010s, following the pioneering works of the 1960s, was due to the fact that almost every source of obsidian has a unique 'geochemical portrait (signature)' (i.e. the content of several chemical elements) which can be determined using analytical methods (WilliamsThorpe 1995; Glascock et al. 1998; Shackley 2005; 
Carter 2014). The establishment of primary sources for obsidian artefacts is very important for understanding the patterns of ancient migrations and contacts.

Obsidian is quite common in the far eastern and northeastern regions of Russia, in the prehistoric assemblages of Kamchatka Peninsula, Chukotka region, Primorye (Maritime) Province, Sakhalin Island, and Kurile Islands (Kuzmin 2010; 2014; Grebennikov et al. 2018). In other parts of eastern Russia - the Amur River basin, northern coast of the Sea of Okhotsk, the basins of the Kolyma and Indigirka rivers, and the High Arctic (Kuzmin 2014; Pitulko et al. 2019) obsidian tools are also present but are not numerous. Actual studies of archaeological obsidian in these regions only began in the early 1990s (Glascock et al. 1996; Shackley et al. 1996), even though in eastern Russia the presence of such artefacts has been known since the end of the nineteenth century (Kuz$\min 2014.144$ ). In this overview, brief information on the current state-of-the-art in obsidian provenance research in eastern Russia is presented, based on the latest summaries (Kuzmin 2010; 2011; 2012; 2014; 2017; 2019).

\section{Methodology of obsidian provenance research and the materials used}

Since the 1960s (Cann, Renfrew 1964; Parks, Tieh 1966; Griffin et al. 1969), the identification of obsidian sources for archaeological materials has been conducted by comparing the geochemical composition (mainly of trace elements - U, Th, Ta, Hf, Lu, $\mathrm{Yb}, \mathrm{Dy}, \mathrm{Tb}, \mathrm{Eu}, \mathrm{Sm}, \mathrm{Nd}$, and some others) of obsidian from primary sources and archaeological assemblages (see Glascock et al. 1998; Shackley 2005). One of the most important conditions for the interpretation of geochemical data is the use of uniform analytical standards, although this is not always the case; therefore, data from different laboratories often cannot be compared (see review: Suda et al. 2018a). In our case studies described here, all measurements for eastern Russia were performed in one laboratory, the Research Reactor Center of the University of Missouri (Columbia, MO, USA) (Glascock et al. 2007), using the same methodology (Glascock et al. 1998). This makes it possible to conduct a direct comparison of the results obtained for both primary ('geological') locales of obsidian and artefacts.

Two main analytical techniques for the geochemical analysis of obsidian in eastern Russia were used by our informal Russian-US group: (1) Neutron Activa- tion Analysis (NAA); and (2) X-ray Fluorescence (XRF). Full descriptions of these methods were given previously (Kuzmin, Glascock 2014; Kuzmin et al. 2002a; 2008; Glascock et al. 2011; Grebennikov et al. 2018), and here I refer to these publications for more details. As for the research strategy employed by our group since 1992, we initially identified, using XRF and NAA, the geochemical groups for a few dozen obsidian artefacts from Primorye Province and the Amur River basin. This made it possible to find out about the number of primary obsidian sources which were exploited (Glascock et al. 1996; Shackley et al. 1996). Afterwards, all major primary sources of obsidian in these regions were examined by NAA (Kuzmin et al. 2002a; Popov et al. 2005; Glascock et al. 2011; Kuzmin et al. 2013). First, the full version of NAA, which allows the determination of 28 elements with high precision (one part-per-million, or $10^{-4 \%}$ ), was used. When the 'geochemical signatures' of the main sources were established, it was possible to use the abridged version of NAA (with measurement of the content of 7-12 elements) for the examination of artefacts only, due to the relatively high cost of the full NAA and its destructive nature (samples become radioactive and need to be utilised as low-level nuclear waste).

Other analytical methods used by different groups of South Korean, Australian and US scholars in eastern Russia and adjacent Northeast Asia were ProtonInduced X-ray Emission (PIXE) and Proton-Induced Gamma-ray Emission (PIGME) (Kim et al. 2007; Doelman et al. 2008); portable XRF and a laser ablation version of the Inductively Coupled Plasma Mass Spectrometry (LA-ICP-MS) (Phillips 2010); and a Prompt Gamma Activation Analysis (PGAA) (Jwa et al. 2018).

As a result of the comparison based on established statistical procedures (Glascock et al. 1998), common geochemical groups for sources and archaeological samples were identified (Kuzmin, Glascock 2014). This made it possible to determine with a high degree of reliability from where the ancient people acquired obsidian. This information constitutes a solid basis for the reconstruction of the procurement and exchange of raw materials in the prehistoric cultural complexes of the entire Northeast Asia.

Various groups of scientists up to early 2019 have analysed about 3110 samples of obsidian from far eastern and northeastern Russia, as well as from adjacent parts of Northeast Asia - the Korean Penin- 
sula, Northeast China (Manchuria), and Hokkaido Island (Tab. 1) (see Kuzmin, Popov 2000; Popov et al. 2005; Kim et al. 2007; Doelman et al. 2008; 2012; 2014; Phillips 2010; Jia et al. 2010; 2013; Kuzmin 2014; Kuzmin, Glascock 2014; Kim 2014; Lee, Kim 2015; Lynch et al. 2016, 2018; Kuzmin et al. 2018; Grebennikov et al. 2018; Chang, Kim 2018; Pitulko et al. 2019). Due to the plethora of information on obsidian geochemistry for the Honshu and Kyushu islands of Japan, available mostly in Japanese only (Sugihara 2014), these regions are excluded from this overview; some English summaries have recently been published and can serve as primary data (see Tsutsumi 2010; Obata et al. 2010; Ikeya 2014; 2015; Sato, Yakushige 2014; Shiba 2014; Shimada 2014; Shimada et al. 2017; Suda et al. 2018b).

\section{Results and discussion}

\section{Sources of obsidian in Primorye Province}

In the southern part of Primorye Province, the main primary source of obsidian (more precisely, waterless volcanic glass) is the Shkotovo (Basaltic) Plateau (Tab. 1, Fig. 1). High quality volcanic glass is associated here with basic rocks (basalts and andesite-basalts), unlike the majority of sources in Northeast Asia which are part of acidic rocks (mainly rhyolites) in volcanic arc positions (Kuzmin et al. 2013; Wada et al. 2014). Although basaltic glasses have been known in Primorye for a long time (Petrov, Zamurueva 1960), their detailed study only began in the 1990s (Kuzmin et al. 2002a). During the eruption of molten basalt, pillow lavas were formed at the contact of the hot basalt mass and cold water or solid surface. Due to rapid cooling of the lava, spherical ('pillow-shaped') bodies with a diameter of $1-5 \mathrm{~m}$ were created (Doelman et al. 2012). The surface layer of pillow lava consists of volcanic glass. Obsidian on the Shkotovo Plateau is present in the form of hyaloclastites, a material formed during the fragmentation of the glassy outer part of pillow lava blocks. Welded crusts with volcanic glass are also known in this region; they are relatively thin (up to $0.3-0.5 \mathrm{~m}$ ) horizons of non-crystallised glass at the contact of the lava flow and the underlying surface.

Another primary source of volcanic glass of acidic (rhyolite) composition is located in the basin of the Gladkaya River in the extreme southwestern part of Primorye (Kuzmin et al. 2002a), but it was not widely exploited in prehistory (Kuzmin 2014; Doelman et al. 2014).

\section{Obsidian source on the Korean Peninsula}

As far as we know today, the single primary obsidian source in Korea of alkaline composition is situated near the modern Paektusan Volcano (Popov et al. in press). It was originally recognised by Kuzmin $e t$ al. (2002a) and Vladimir K. Popov et al. (2005), but for a long time our knowledge was based exclusively on archaeological materials (i.e. obsidian artefacts). Only a handful of 'geological' samples with unknown exact location - somewhere within the northern part of Korea, called today the Democratic People's Republic of Korea, or North Korea - were analysed in the early-mid 2010s (Kim 2014.169; Yi, Jwa, 2016; Jwa et al. 2018; Popov et al. in press).

\begin{tabular}{|lccl|}
\hline Regions & $\begin{array}{c}\text { Geological } \\
\text { samples }\end{array}$ & $\begin{array}{c}\text { Archaeological } \\
\text { samples }\end{array}$ & Main obsidian sources* \\
\hline Primorye (Maritime) Province & 102 & 390 & BP, PA \\
\hline Amur River basin & 12 & 39 & OP, BP, SH-OK \\
\hline Sakhalin Island & - & 206 & SH-OK, AK \\
\hline Kamchatka Peninsula & 63 & 444 & KAM-O1 - KAM-15 \\
\hline Kurile Islands & - & 773 & SH-OK, KAM-O1, KAM-O2, KAM-O4, KAM-O5, KAM-07 \\
\hline Chukotka & 37 & 216 & LK, KAM-O1, KAM-O3, KAM-O8, VAK \\
\hline Siberian Arctic (Zhokhov I.) & - & 14 & LK \\
\hline Manchuria (Northeast China) & - & 533 & PA, BP \\
\hline Korean Peninsula & 14 & 211 & PA, KO \\
\hline Hokkaido Island & 53 & - & SH-OK, AK, TM \\
\hline Number of samples & 281 & $\mathbf{2 8 2 6}$ & 3107*t: \\
\hline * BP Basaltic Plateau; PA Paektusan Volcano region; OP Obluchie Plateau; SH-OK Shirataki and Oketo; AK Akaigawa; \\
$\begin{array}{l}\text { KAM-Or - KAM-15 various Kamchatkan sources (see for details: Grebennikov, Kuzmin 2017); LK Lake Krasnoe; VAK } \\
\text { Vakarevo type; KO Koshidake; TM Tokachi-Mitsumata. }\end{array}$ \\
*** Total number of obsidian samples analysed for this overview (see text for references). \\
\hline
\end{tabular}

Tab. 1. Number of samples analysed for each region of Northeast Asia (1992-2019), and major obsidian sources used in prehistory. 


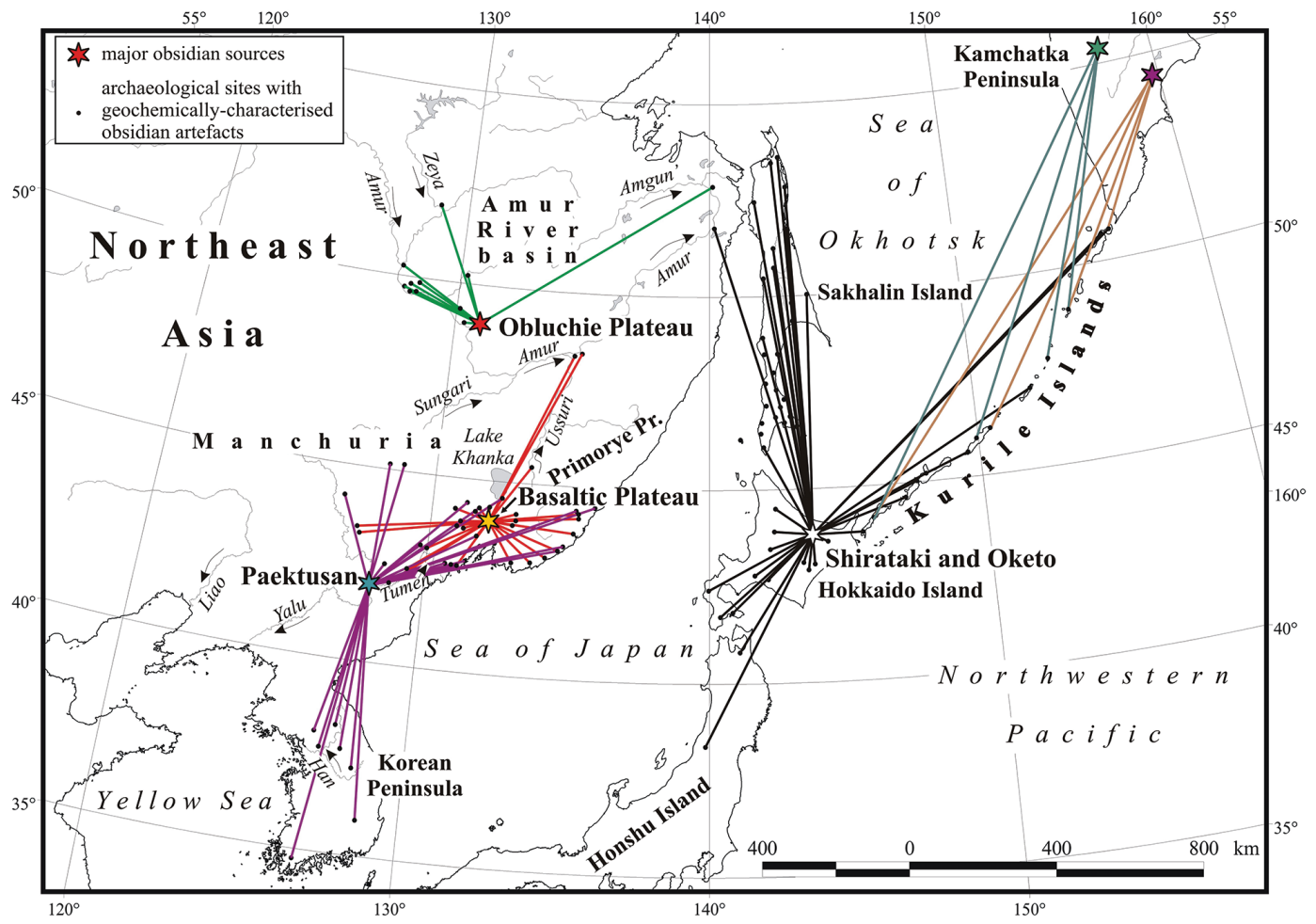

Fig. 1. Prehistoric obsidian exchange/trade networks in the southern Russian Far East and neighbouring Northeast Asia (after Kuzmin 2017, modified).

Nevertheless, all these data testify in favour of a single geochemical group which reflects the 'geochemical signature' of a primary source. Based on comprehensive analysis of all available evidence, it is concluded that the primary obsidian locale previously named 'Paektusan' or PNK1 is situated somewhere south of the Paektusan Volcano (Fig. 1). It is hoped that in the near future it will be possible to pinpoint the exact position of this important source in the logistically difficult region of North Korea.

\section{Sources of obsidian in the Amur River basin}

The major primary source of volcanic glass in the Amur River basin is known from the Obluchie Plateau, where it is confined to basaltic hyaloclastites (Glascock et al. 2011) (Tab. 1; Fig. 1); its geological position is similar to the Shkotovo Plateau. There are also data about the existence of another kind of basaltic obsidian in this region, but the exact location of its source is still unknown. In the meantime, we called it 'Samarga' (Kuzmin 2014.Fig. 6.1), and suggest that it is situated in the Samarga River basin, the northern part of Primorye Province (Kuzmin et al. 2002a; Glascock et al. 2011).

\section{Sources of obsidian on Hokkaido Island}

Our informal Russian-US-Japanese group conducted NAA analyses of four major obsidian sources on Hokkaido Island - Shirataki (with two sub-sources), Oke- to (with two sub-sources), Akaigawa, and TokachiMitsumata (Kuzmin et al. 2002b; 2013; Kuzmin, Glascock 2007). Other primary obsidian locales from Hokkaido (around 17 in number), consisting of $c$. 17-20 geochemical groups, were investigated by Keiji Wada et al. (2014) and Jeffrey R. Ferguson et al. (2014). All these sources are situated in a volcanic arc setting (Wakita 2013; Wada et al. 2014).

\section{Sources of obsidian on Kamchatka Peninsula} The Kamchatka Peninsula of eastern Russia is one of the few regions in the world with a high concentration of obsidian sources, along with the Japanese Islands (Kannari et al. 2014.Fig. 4.2) and Mesoamerica (Glascock et al. 1998; 2010). Today, at least 30 to 40 locales of acidic volcanic glass (associated with rhyolites and rhyodacites) are known in Kamchatka (Grebennikov, Kuzmin 2017; Grebennikov et al. 2010). They are genetically related to the volcanism of the subduction zone of the Kurile-Kamchatkan arc (see Khain 1994). The major problem in the geological investigations of this region is its remoteness, and the logistical aspect of fieldwork is difficult and costly.

Currently, our Russian-US group has determined the geochemical composition of only 16 primary sources of Kamchatkan obsidian (Grebennikov, Kuzmin 2017). This is due to the difficulty of carrying out 
fieldwork in the Sredinny Range which is devoid of roads and settlements (Grebennikov et al. 2010. 90). Sources are usually lava flows, extrusive (embedded in other rocks) bodies and pyroclastic flows. Of the 30 to 40 primary locales, 14 sources were actively used in prehistory.

\section{Obsidian source in the Chukotka region (North- eastern Siberia)}

It has been known for a long time that an obsidian source exists on Lake Krasnoe (with krasnoe meaning 'red') in the lower reaches of the Anadyr River (Nasedkin 1983) (Fig. 2), but more precise information about it was non-existent before our fieldwork in 2009. As a result of a survey and study of obsidian and other rocks on the shore and around Lake Krasnoe, we were able to obtain reliable data on the geology and geochemistry of this source (Popov et al. 2017; Grebennikov et al. 2018). Obsidian in Chukotka is part of the rhyolites of the West Koryak volcanic belt, and it can be found as pebbles and small boulders on the eastern shore of the lake; the primary source is perhaps currently under water (Grebennikov et al. 2018.609).

Prehistoric obsidian exchange networks in the One of the main tasks of studying obsidian for archaeological purposes is to establish the patterns of its acquisition from primary sources, which allows reliable reconstructions of obsidian exchange networks, as well as human contacts and migrations in prehistory (Williams-Thorpe 1995; see also Kuzmin 2012 ; 2015; 2017). Currently, the existence of several large-scale exchange systems has been established (using obsidian as a commodity) for the southern part of the Russian Far East and adjacent regions, and for Northeastern Siberia (Figs. 1-2). Obsidian in these regions was most intensively exploited in the Stone Age - the Upper Palaeolithic (c. 2500012000 years ago) and the Neolithic (c. 12 000-3000 years ago) (Kuzmin 2011; 2015). In the Bronze and Early Iron ages (c. 3000-1500 years ago), the value of obsidian as a raw material almost vanished, with the exception of Kamchatka and the Siberian Arctic, where the ancient populations continued to use it until the arrival of Russian settlers in the $17^{\text {th }}-18^{\text {th }}$ centuries $\mathrm{AD}$, who introduced metals.

Three obsidian exchange networks have been reconstructed in the mainland Russian Far East (Fig. 1; Tab. 1), centred around the sources of the Shkotovo and Obluchie plateaus, and the Paektusan Volcano. While obsidian from the Shkotovo Plateau and the
Paektusan sources is widely distributed in the region, including Primorye, the Korean Peninsula, Manchuria, and the Amur River basin, the Obluchie Plateau supplied only the Amur River basin. The distances from the sources to the utilisation sites in Primorye and the Amur River basin range from a few kilometres to $660-700 \mathrm{~km}$ in a straight line, and for the Paektusan obsidian network it is even further, up to $800 \mathrm{~km}$ (Fig. 1). The extensive exchange of obsidian centred around the Paektusan source was initially established by our group in the early $2000 \mathrm{~s}$ (Kuzmin et al. 2002a); subsequent studies confirmed this conclusion (Doelman et al. 2008; 2012).

In insular Russian Far East - Sakhalin Island and the Kurile Islands - the main sources of obsidian were Shirataki and Oketo locales on Hokkaido Island (Fig. 1). Obsidian from the Shirataki source was also detected on the mainland (lower reaches of the Amur River), and it was brought there $c .8000$ years ago (Glascock et al. 2011). The distance from the Hokkaido sources to the utilisation sites in some cases exceeds $1000 \mathrm{~km}$ in a straight line. For the Kurile Islands, the use of obsidian from several Kamchatkan sources has been established (Fig. 1), with distances of up to $1400-1500 \mathrm{~km}$ as the crow flies. These obsidian exchange networks are an example of the super-long transport of raw materials, and their existence would be impossible without the use of watercraft from c. 10000 years ago onwards (Kuzmin 2016; 2017).

Based on current knowledge on obsidian sourcing in insular Northeast Asia, one can confidently say that obsidian from sources in the Japanese Islands almost never reached the mainland part of the region, except the lower Amur River basin (Kuzmin et al. 2013) and the southernmost part of the Korean Peninsula (Kim 2014; Kim et al. 2007; Lee, Kim 2015). As for the latter, the main supplier of obsidian was the Koshidake source in northern Kyushu Island; it was also transported to the Ryukyu Archipelago in later prehistory (Obata et al. 2010; Kuzmin 2010.Fig. 8.8 ). The use of watercraft for the creation of this network since the Upper Palaeolithic is evident, because even during the Last Glacial Maximum, c. 27000 23000 years ago, the Korea (Tsushima) Strait between the Korean Peninsula and Kyushu Island existed, with c. $20 \mathrm{~km}$ width (Kuzmin 2017.Fig. 4).

Research conducted on the Kamchatka Peninsula by our group allowed us to reconstruct several obsidian exchange networks, with distances from sources to utilisation sites up to $600-650 \mathrm{~km}$ in a straight line. 


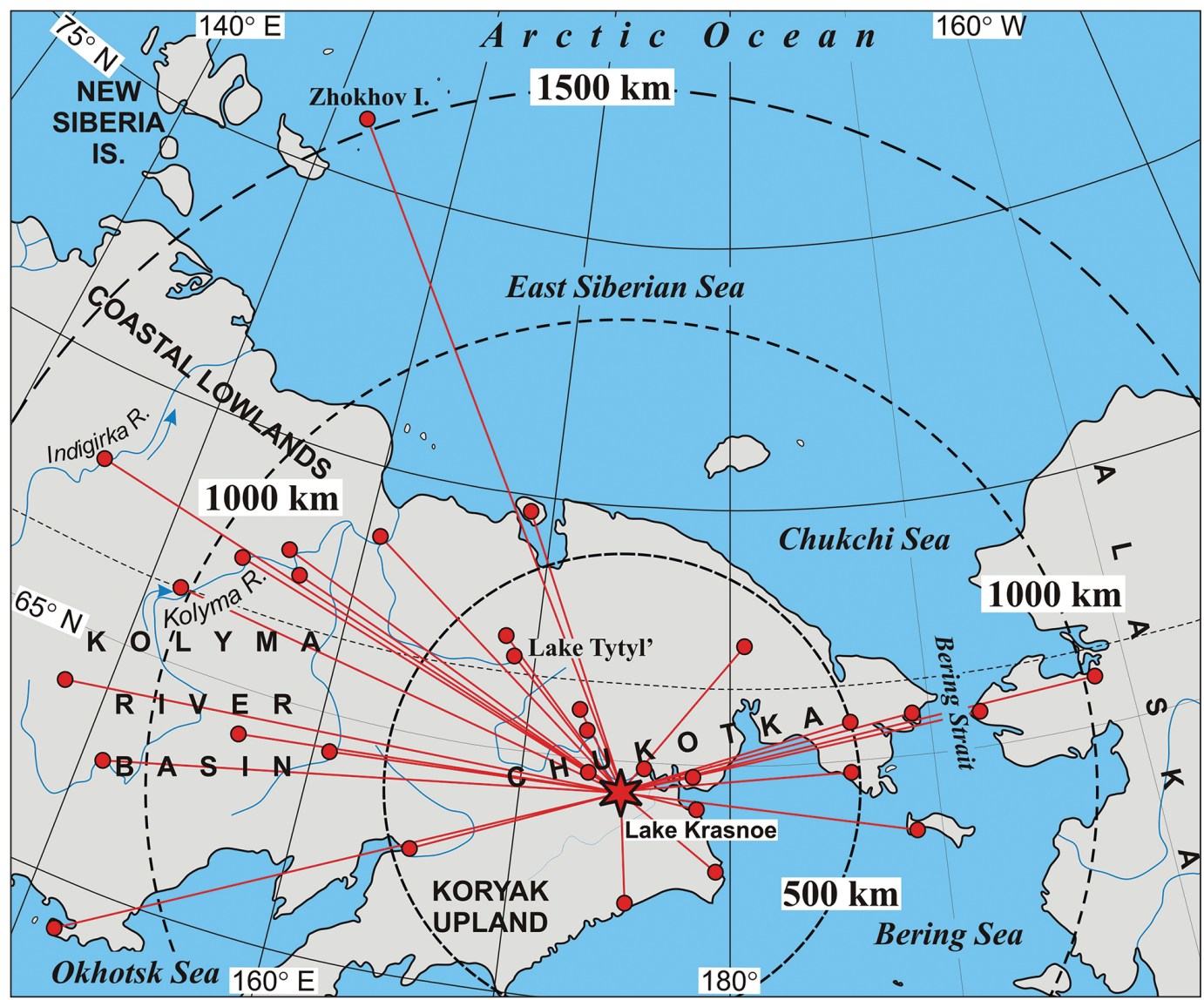

Fig. 2. Distribution of obsidian of the Lake Krasnoe source in Northeastern Siberia and Alaska (modified from Kuzmin 2019 and Pitulko et al. 2019). Red circles are sites with geochemically-characterised obsidian artefacts belonging to the Lake Krasnoe source.

The study of the obsidian sources in Kamchatka is still in its initial stage, primarily due to the high cost of fieldwork in the more remote parts of the peninsula where the majority of sources are located. Currently, on the basis of general geological and geochemical data, the most promising areas that require research have been identified (Grebennikov, Kuzmin 2017).

Northeastern Siberia (Chukotka and adjacent areas) is a relatively new territory for the study of obsidian sources at the modern methodological level. According to the results of geochemical analyses of $c .220$ artefacts from the Chukotka region, a single source of obsidian was found, at Lake Krasnoe (Grebenni$k o v$ et al. 2018). The raw materials from this locale spread beyond Chukotka - to the Koryak Uplands, the basin of the Kolyma River, and Alaska (Grebennikov et al. 2018; Kuzmin et al. 2018; Rasic 2016) (Fig. 2). The distance from the source to the utilisation sites in some cases exceeds $1000 \mathrm{~km}$ in a straight line.

The latest data from this region were obtained for the Zhokhov site in the High Arctic $\left(76^{\circ} \mathrm{N}\right.$ latitude).
Here 79 obsidian artefacts were found in the Mesolithic cultural layer, dated to $c$. 8900-8600 years ago (Pitulko, Pavlova 2016). A provenance study of 14 artefacts showed that the raw material of all of them originated from the Lake Krasnoe source (Pitulko et al. 2019). The straight distance between site and the source is $c .1500 \mathrm{~km}$; considering the coastline of the Arctic Ocean at the time of human occupation, it would be $c .2000 \mathrm{~km}$ (Fig. 2; Pitulko et al. 2019 . Fig. 7). The obsidian from the Zhokhov site along with other archaeological localities in Northeastern Siberia (Kuzmin et al. 2018) is evidence of the super-long-distance transport of raw material. It also shows that the size of the human interaction sphere in the Mesolithic of the Siberian Arctic was very large, up to $c .4000000 \mathrm{~km}^{2}$ (Pitulko et al. 2019).

An important feature of obsidian exploitation by ancient humans in the eastern regions of Russia is the use of this raw material from several sources at a given site from the same cultural component; such cases have been repeatedly noted in Kamchatka, Primorye, Sakhalin Island and the Kurile Islands (Kuzmin 2014). The clearest example in this respect is 
the multilayered Ushki site cluster in Kamchatka (Kuzmin et al. 2008). In the Late Pleistocene Layer 7 (dated to $c$. 12600-17400 years ago), seven sources of obsidian were identified. In the Final Pleistocene Layer 6 (dated to $c$. 11900-12900 years ago), the use of obsidian from four primary sources was detected. In the Holocene strata 5-1 (dated to $c$. 30010100 years ago), obsidian from one to six sources was determined. The distance from the site to the sources of obsidian is $c .140-260 \mathrm{~km}$ in a straight line, and the sources are $c .250-500 \mathrm{~km}$ apart. This complex strategy in the acquisition of valuable raw material in the harsh sub-Arctic environment, revealed after obsidian provenance research done by our group (see Kuzmin et al. 2008; Grebennikov, Kuzmin 2017; Grebennikov et al. 2010), represents a striking pattern of human adaptation to the natural environment in northeastern Russia in the late Upper Palaeolithic, Mesolithic and Neolithic.

One of the most important aspects in the study of the acquisition and use of archaeological obsidian is the mechanism for acquiring raw material from remote sources. In the southern Russian Far East, the travel distance of obsidian pebbles transported by rivers is up to $30-50 \mathrm{~km}$ downstream from the source (Pantukhina 2007). Because today the presence of long-distance movement of obsidian, which greatly exceeds the range of obsidian transport by natural agents, is well-established (Figs. 1-2; Tab. 1 ), the issues related to exchange of this high-quality raw material are of great significance. Studies done in the Mediterranean and Near East in the 1960s (Renfrew 1975) allowed the creation of the 'downthe-line' concept of prehistoric trade/exchange. The main components of this concept are: (1) a supply $z o n e$, with a radius of up to $300 \mathrm{~km}$ from the centre where the utilisation site is located, with the share of obsidian in the composition of the raw materials up to $80 \%$; and (2) a contact zone beyond the supply zone, inhabitants of which could not easily visit the sources of obsidian due to the large distance to them, and they exchanged (traded) obsidian with people of the supply zone; the share of obsidian ranges from $30-40 \%$ to $0.1 \%$.

In many cases established by our group for eastern Russia, the archaeological obsidians are separated from the primary sources by distances greater than c. $300 \mathrm{~km}$ (Figs. 1-2), and this is evidence of welldeveloped exchange/trade networks, especially in Northeastern Siberia where the raw material from an obsidian source of Lake Krasnoe was spread in an enormously large area, with straight distances be- tween end points up to $c$. 2000-2250km (Fig. 2). This kind of obsidian spread across an enormously large region can be called 'super-long-distance' exchange. It would be impossible to maintain the acquisition of obsidian from so remote a source without primitive trade and/or exchange, as is also evident in some other parts of Asia (Campbell, Healey 2018) and other continents (Haines, Glascock 2013).

The reconstruction of exchange/trade networks requires a detailed study of the petrographic composition of stone artefacts, and technical and technological investigation of obsidian products (tools, along with flakes and other sub-products), in order to understand the nature of raw materials brought to utilisation sites - in the form of either angular blocks, cores or finished products. Using the Zhokhov site (Mesolithic, c. 8900-8600 years ago) as a case study, one can conclude that obsidian was used for making microblades (Pitulko et al. 2019). No obsidian cores were found, although it seems that microblade manufacture occurred at the site. Therefore, obsidian appeared at the Zhokhov site in a semi-ready form (cores and blades). Other rocks from the Zhokhov site, including local flint and sandstone, and 'exotic' chalcedony, were also used as raw materials for the manufacture of microblades by pressure flaking ( $\mathrm{Pi}$ tulko et al. 2012). The technological analysis of the lithics concluded that the raw material was not in the form of blocks, but prepared cores and large blades were transported to the site. This is true in terms of both local and 'exotic' rocks (Pitulko et al. 2012. 240).

Some information on the distribution of obsidian artefacts and their typological characteristics exists for other parts of Northeastern Siberia (Fig. 2). At archaeological sites in the lower Kolyma River course dated to the Neolithic (c. 7000-3000 years ago), the main obsidian artefacts are blades and their fragments, flakes, insets, and arrowheads, while a few obsidian prismatic cores were also recovered (Kuzmin et al. 2018). It seems that obsidian was brought to the lower Kolyma River region from far away in the form of cores, and blade-making was performed locally. The high value of obsidian as an 'exotic' raw material forced prehistoric people to use cores to complete exhaustion. Several sites with obsidian were excavated at the Lake Tytyl' cluster in western Chukotka (Kiryak 2010), and they belong to the Mesolithic (c. 11200 years ago) and Neolithic (c. 4800 years ago). Some of the artefacts (the exact number is unknown, but it is relatively small), especially points, are made of obsidian. It was suggested 
that this area may have served as a 'hub' for the exchange of obsidian between the source in eastern Chukotka and the Kolyma River basin and territories west of the Kolyma River (Pitulko et al. 2019) (see Fig. 2). Because in the Kolyma River and Lake Tytyl' regions obsidian was traded as an 'exotic' raw material with populations near the source located at Lake Krasnoe (Grebennikov et al. 2018; Kuzmin et al. 2018) - at least $c$. 400-800 km away in a straight line - the exchange of it was carried out as prepared cores and tools rather than unworked pieces.

As far as I know, similar work has not yet been carried out in far eastern Russia. Some of the steps taken in this direction for the southern Russian Far East and Manchuria (see Doelman et al. 2008; 2012; 2014) are still at a very preliminary stage.

\section{Conclusions}

Over the last $25^{+}$years, significant progress has been achieved in obsidian provenance research in eastern Russia. The main networks of prehistoric exchange / trade of obsidian were reconstructed in the continental and insular parts of the southern Russian Far East; more work is underway in the northern part of the Russian Far East (Kamchatka Peninsula) and in Northeastern Siberia.

However, several issues still remain unresolved. The lack of standardisation for geochemical analyses conducted by different researchers has often made it impossible to compare the results obtained. To over- come this problem, a parallel analysis of obsidian source samples from Hokkaido Island was conducted in several laboratories, followed by interpretation of the results and determination of the optimal analytical strategy (Suda et al. 2018a). The Kamchatka Peninsula remains the least studied region in eastern Russia in terms of the provenance of archaeological obsidian; the exact positions of seven sources used in prehistory are currently unknown (Grebennikov, Kuzmin 2017). The question of the mechanism of obsidian exchange between the populations near the sources and those who lived at a considerable distance from the primary obsidian locales requires in-depth study.

This study was conducted on the State Assignment of the Sobolev Institute of Geology and Mineralogy, Siberian Branch of the Russian Academy of Sciences, with funding provided by the Ministry of Science and Higher Education of the Russian Federation. I am grateful to several colleagues for long-term collaboration, especially to Dr. Vladimir K. Popov (deceased), Dr. Michael D. Glascock, Dr. Andrei V. Grebennikov, and Dr. Vladimir V. Pitulko; to Prof. Emeriti Akira Ono and Jong-Chan Kim; and to Prof. Clive Oppenheimer. I am grateful to Prof. Mihael Budja for the invitation to participate in this volume, and to an anonymous reviewer for useful comments. Dr. Susan Keates kindly corrected the grammar, although all possible mistakes belong to me.

\section{References}

Campbell S., Healey E. 2018. Diversity in obsidian use in the prehistoric and early historic Middle East. Quaternary International 468: 141-154.

https://doi.org/10.1016/j.quaint.2017.09.023

Cann J. R., Renfrew C. 1964. The characterization of obsidian and its application to the Mediterranean region. Proceedings of the Prehistoric Society 30: 111-133.

Carter T. 2014. The contribution of obsidian characterization studies to early prehistoric archaeology. In M. Yamada, A. Ono (eds.), Lithic Raw Material Exploitation and Circulation in Prehistory. University of Liege. Liege: 2233.
Chang Y. C., Kim J. C. 2018. Provenance of obsidian artifacts from the Wolseongdong Paleolithic site, Korea, and its archaeological implications. Quaternary International 467: 360-368.

https://doi.org/10.1016/j.quaint.2017.11.034

Doelman T., Jia P. W., Torrence R., and Popov V. K. 2014. Remains of a puzzle: the distribution of volcanic glass artifacts from sources in Northeast China and Far East Russia. Lithic Technology 39: 81-95.

https://doi.org/10.1179/0197726114Z.00000000035

Doelman T., Torrence R., Popov V., Ionescu M., Kluyev N., Sleptsov I., Pantyukhina I., White P., and Clements M. 
2008. Source selectivity: an assessment of volcanic glass sources in the southern Primorye region, Far East Russia. Geoarchaeology 23: 243-273.

https://doi.org/10.1002/gea.20216

Doelman T., Torrence R., Popov V., Kluyev N., and SleptSov I. 2012. Volcanic glass procurement and use in the Late Paleolithic, central Primorye, Far East Russia. In I. Liritzis, C. M. Stevenson (eds.), Obsidian and Ancient Manufactured Glasses. University of New Mexico Press. Albuquerque: 97-114.

Ferguson J. R., Glascock M. D., Izuho M., Mukai M., Wada K., and Sato H. 2014. Multi-method characterisation of obsidian source compositional groups in Hokkaido Island (Japan). In A. Ono, M. D. Glascock, Y. V. Kuzmin, and Y. Suda (eds.), Methodological Issues for Characterisation and Provenance Studies of Obsidian in Northeast Asia. British Archaeological Reports IS 2620. Archaeopress. Oxford: 13-32.

Glascock M. D., Braswell G. E., and Cobean R. H. 1998. A systematic approach to obsidian source characterization. In M. S. Shackley (ed.), Archaeological Obsidian Studies: Method and Theory. Plenum Press. New York \& London: 15-65.

Glascock M. D., Krupianko A. A., Kuzmin Y. V., Shackley M. S., and Tabarev A. V. 1996. Geochemical characterization of obsidian artifacts from prehistoric sites in the Russian Far East: initial study. In I. S. Zhushchikhovskaya, A. L. Ivliev, and N. N. Kradin (eds.), Arkheologiya Severnoi Patsifiki. Dalnauka Press. Vladivostok: 406-410.

Glascock M. D., Kuzmin Y. V., Grebennikov A. V., Popov V. K., Medvedev V. E., Shewkomud I. Y., and Zaitsev N. N. 2011. Obsidian provenance for prehistoric complexes in the Amur River basin (Russian Far East). Journal of Archaeological Science 38: 1832-1841.

https://doi.org/10.1016/j.jas.2011.03.022

Glascock M. D., Speakman R. J., and Neff H. 2007. Archaeometry at the University of Missouri Research Reactor and the provenance of obsidian artefacts in North America. Archaeometry 49: 343-357.

https://doi.org/10.1111/j.1475-4754.2007.00305.x

Glascock M. D., Weigand P. C., Esparza López R., Ohnersorgen M. A., Garduño Ambriz M., Mountjoy J. B., and Darling J. A. 2010. Geochemical characterisation of obsidian in western Mexico: the sources in Jalisco, Nayarit, and Zacatecas. In Y. V. Kuzmin, M. D. Glascock (eds.), Crossing the Straits: Prehistoric Obsidian Source Exploitation in the North Pacific Rim. British Archaeological Reports IS 2152. Archaeopress. 0xford: 201-217.

Grebennikov A. V., Kuzmin Y. V. 2017. The identification of archaeological obsidian sources on Kamchatka Penin- sula (Russian Far East) using geochemical and geological data: current progress. Quaternary International 442B: 95-103. https://doi.org/10.1016/j.quaint.2016.03.020

Grebennikov A. V., Kuzmin Y. V., Glascock M. D., Popov V. K., Budnitskiy S. Y., Dikova M. A., and Nozdrachev E. A. 2018. The Lake Krasnoe obsidian source in Chukotka (Northeastern Siberia): geological and geochemical frameworks for provenance studies in Beringia. Archaeological and Anthropological Sciences 10: 599-614. https://doi.org/10.1007/s12520-016-0379-z

Grebennikov A. V., Popov V. K., Glascock M. D., Speakman R. J., Kuzmin Y. V., and Ptashinsky A. V. 2010. Obsidian provenance studies on Kamchatka Peninsula (Far Eastern Russia): 2003-9 results. In Y. V. Kuzmin, M. D. Glascock (eds.), Crossing the Straits: Prehistoric Obsidian Source Exploitation in the North Pacific Rim. British Archaeological Reports IS 2152. Archaeopress. Oxford: 89-120.

Griffin J. B., Gordus A. A., and Wright G. A. 1969. Identification of the sources of Hopewellian obsidian in the Middle West. American Antiquity 34: 1-14.

Haines H. R., Glascock M. D. 2013. A glass menagerie of meaning: obsidian exchange in Mesoamerica. In C. Helmke, J. Nielsen (eds.), The Maya in a Mesoamerican Context: Comparative Approaches to Maya Studies. Verlag Anton Saurwein. Markt Schwaben: 197-208.

Ikeya N. 2014. Identification of archaeological obsidian sources in Kanto and Chubu regions (central Japan) by Energy Dispersive X-ray Fluorescence analysis. In A. Ono, M. D. Glascock, Y. V. Kuzmin, and Y. Suda (eds.), Methodological Issues for Characterisation and Provenance Studies of Obsidian in Northeast Asia. British Archaeological Reports IS 2620. Archaeopress. Oxford: 111-123.

2015. Maritime transport of obsidian in Japan during the Upper Paleolithic. In Y. Kaifu, M. Izuho, T. Goebel, and A. Ono (eds.), Emergence and Diversity of Modern Human Behavior in Paleolithic Asia. Texas A\&M University Press. College Station: 362-375.

Jia P. W., Doelman T., Chen C., Zhao H., Lin S., Torrence R., and Glascock M. D. 2010. Moving sources: a preliminary study of volcanic glass artifact distributions in Northeast China using pXRF. Journal of Archaeological Science 37: 1670-1677.

https://doi.org/10.1016/j.jas.2010.01.027

Jia P. W., Doelman T., Torrence R., and Glascock M. D. 2013. New pieces: the acquisition and distribution of volcanic glass sources in Northeast China during the Holocene. Journal of Archaeological Science 40: 971-982. https://doi.org/10.1016/j.jas.2012.09.001 
Jwa Y.-J., Yi S., Jin M.-E., Kasztovszky Z., Harsányi I., and Sun G.-M. 2018. Application of Prompt Gamma Activation Analysis to provenance study of the Korean obsidian artefacts. Journal of Archaeological Science: Reports 20: 374-381. https://doi.org/10.1016/j.jasrep.2018.05.016

Kannari T., Nagai M., and Sugihara S. 2014. The effectiveness of elemental intensity ratios for sourcing obsidian artefacts using Energy Dispersive X-ray Fluorescence spectrometry: A case study from Japan. In A. Ono, M. D. Glascock, Y. V. Kuzmin, and Y. Suda (eds.), Methodological Issues for Characterisation and Provenance Studies of Obsidian in Northeast Asia. British Archaeological Reports IS 2620. Archaeopress. 0xford: 47-66.

Khain V. E. 1994. Geology of Northern Eurasia (ExUSSR). Part 2. Phanerozoic Fold Belts and Young Platforms. Gebrüder Borntraeger. Berlin \& Stuttgart.

Kim J.-C. 2014. The Paektusan Volcano source and geochemical analysis of archaeological obsidians in Korea. In A. Ono, M. D. Glascock, Y. V. Kuzmin, and Y. Suda (eds.), Methodological Issues for Characterisation and Provenance Studies of Obsidian in Northeast Asia. British Archaeological Reports IS 2620. Archaeopress. Oxford: 167178.

Kim J. C., Kim D. K., Yoon M., Yun C. C., Park G., Woo H. J., Hong M.-Y., and Lee G. K. 2007. PIXE provenancing of obsidian artefacts from Paleolithic Sites in Korea. Bulletin of the Indo-Pacific Prehistory Association 27: 122-128.

Kiryak (Dikova) M. A. 2010. The Stone Age of Chukotka, North-Eastern Siberia (New Materials). British Archaeological Reports IS 2099. Archaeopress. Oxford.

Kuzmin Y. V. 2010. Crossing mountains, rivers, and straits: A review of the current evidence for prehistoric obsidian exchange in Northeast Asia. In Y. V. Kuzmin, M. D. Glascock (eds.), Crossing the Straits: Prehistoric Obsidian Source Exploitation in the North Pacific Rim. British Archaeological Reports IS 2152. Archaeopress. Oxford: 137153.

2011. The patterns of obsidian exploitation in the late Upper Pleistocene of the Russian Far East and neighbouring Northeast Asia. Natural Resource, Environment and Humans 1 (Meiji University Center for Obsidian and Lithic Studies): 67-82.

2012. Long-distance obsidian transport in prehistoric Northeast Asia. Bulletin of the Indo-Pacific Prehistory Association 32: 1-5.

2014. Geoarchaeological aspects of obsidian source studies in the southern Russian Far East and brief comparison with neighbouring regions. In A. Ono, M. D. Glas- cock, Y. V. Kuzmin, and Y. Suda (eds.), Methodological Issues for Characterisation and Provenance Studies of Obsidian in Northeast Asia. British Archaeological Reports IS 2620. Archaeopress. Oxford: 143-165.

2015. Northern and northeastern Asia: archaeology. In P. Bellwood (ed.), The Global Prehistory of Human Migration. Wiley-Blackwell. Chichester: 191-196.

2016. Colonization and early human migrations in the insular Russian Far East: a view from the mid-2010s. Journal of Island \& Coastal Archaeology 11: 122-132.

2017. Obsidian as a commodity to investigate human migrations in the Upper Paleolithic, Neolithic, and Paleometal of Northeast Asia. Quaternary International 442B: 5-11.

https://doi.org/10.1016/j.quaint.2016.03.021

2019. Obsidian acquisition and exchange in prehistoric cultures of the Russian Far East and Northeast Siberia: A review of the 25 years of research. Prehistoric Archaeology. Journal of Interdisciplinary Studies 1: 92107 (in Russian with English abstract).

Kuzmin Y. V., Alekseyev A. N., Dyakonov V. M., Grebennikov A. V., and Glascock M. D. 2018. Determination of the source for prehistoric obsidian artifacts from the lower reaches of Kolyma River, Northeastern Siberia, Russia, and its wider implications. Quaternary International 476: 95-101. https://doi.org/10.1016/j.quaint.2018.02.017

Kuzmin Y. V., Glascock M. D. 2007. Two islands in the ocean: prehistoric obsidian exchange between Sakhalin and Hokkaido, Northeast Asia. Journal of Island \& Coastal Archaeology 2: 99-120.

2014. The Neutron Activation Analysis of volcanic glasses in the Russian Far East and neighbouring Northeast Asia: a summary of the first 20 years of research. In A. Ono, M. D. Glascock, Y. V. Kuzmin, and Y. Suda (eds.), Methodological Issues for Characterisation and Provenance Studies of Obsidian in Northeast Asia. British Archaeological Reports IS 2620. Archaeopress. Oxford: 85-93.

Kuzmin Y. V., Glascock M. D., and Izuho M. 2013. The geochemistry of the major sources of archaeological obsidian on Hokkaido Island (Japan): Shirataki and Oketo. Archaeometry 55: 355-369.

https://doi.org/10.1111/j.1475-4754.2012.00694.x

Kuzmin Y. V., Glascock M. D., and Sato H. 2002b. Sources of archaeological obsidian on Sakhalin Island (Russian Far East). Journal of Archaeological Science 29: 741750. https://doi.org/10.1006/jasc.2001.0748 
Kuzmin Y. V., Popov V. K. (eds.). 2000. Volcanic Glasses of the Russian Far East: Geological and Archaeological Aspects. Far Eastern Geological Institute. Vladivostok (in Russian with English abstract).

Kuzmin Y. V., Popov V. K., Glascock M. D., and Shackley M. S. 2002a. Sources of archaeological volcanic glass in the Primorye (Maritime) Province, Russian Far East. $A r$ chaeometry 44: 505-515.

https://doi.org/10.1111/1475-4754.t01-1-00082

Kuzmin Y. V., Speakman R. J., Glascock M. D., Popov V. K., Grebennikov A. V., Dikova M. A., and Ptashinsky A. V. 2008. Obsidian use at the Ushki Lake complex, Kamchatka Peninsula (Northeastern Siberia): implications for terminal Pleistocene and Early Holocene human migrations in Beringia. Journal of Archaeological Science 35: 21792187. https://doi.org/10.1016/j.jas.2008.02.001

Lee G. K., Kim J. C. 2015. Obsidians from the Sinbuk archaeological site in Korea - evidences for strait crossing and long-distance exchange of raw material in Paleolithic Age. Journal of Archaeological Science: Reports 2: 458466. https://doi.org/10.1016/j.jasrep.2015.04.005

Lynch S. C., Kato H., and Weber A. W. 2018. Obsidian resource use from the Jomon to Okhotsk period on Rebun Island: an analysis of archaeological obsidian. Journal of Archaeological Science: Reports 17: 1007-1017. https://doi.org/10.1016/j.jasrep.2016.05.004

Lynch S. C., Locock A. J., Duke M. J. M., and Weber A. W. 2016. Evaluating the applicability of portable-XRF for the characterization of Hokkaido obsidian sources: a comparison with INAA, ICP-MS and EPMA. Journal of Radioanalyical \& Nuclear Chemistry 309: 257-265.

https://doi.org/10.1007/s10967-016-4766-9

Nasedkin V. V. 1983. Kislyi Vulkanizm $i$ Vodosoderzhashchie Stekla Severo-Vostoka SSSR (The Acidic Volcanism and Water-Containing Glasses of the Northeastern USSR). Nauka Publishers. Moscow (in Russian).

Obata H., Morimoto I., and Kakubuchi S. 2010. Obsidian trade between sources on northwestern Kyushu Island and Ryukyu Archipelago (Japan) during Jomon period. In Y. V. Kuzmin, M. D. Glascock (eds.), Crossing the Straits: Prehistoric Obsidian Source Exploitation in the North Pacific Rim. British Archaeological Reports IS 2152. Archaeopress. Oxford: 57-71.

Pantukhina I. 2007. The role of raw material in microblade technology at three Late Palaeolithic sites, Russian Far East. Bulletin of the Indo-Pacific Prehistory Association 27: 144-153.
Parks G. A., Tieh T. T. 1966. Identifying the geographical source for artefact obsidian. Nature 211: 289-290. https://doi.org/10.1038/211289a0

Petrov V. P., Zamurueva M. G. 1960. 0 steklovatykh sharovykh lavakh r. Levaia Lefu na Dal'nem Vostoke (About the glassy pillow lavas of the Levaya Lefu River in the Far East). Izvestiya Akademii Nauk SSSR. Seriya geologicheskaia 11: 69-75. (in Russian)

Phillips S. C. 2010. Bridging the gap between two obsidian source areas in Northeast Asia: LA-ICP-MS analysis of obsidian artefacts from the Kurile Islands of the Russian Far East. In Y. V. Kuzmin, M. D. Glascock (eds.), Crossing the Straits: Prehistoric Obsidian Source Exploitation in the North Pacific Rim. British Archaeological Reports IS 2152. Archaeopress. Oxford: 121-136.

Pitulko V. V., Kuzmin Y. V., Glascock M. D., Pavlova E. Y., and Grebennikov A. V. 2019. 'They came from the ends of the earth': Long-distance exchange of obsidian in the High Arctic during the Early Holocene. Antiquity 93: 2844. https://doi.org/10.15184/aqy.2019.2

Pitulko V. V., Pavlova E. Y. 2016. Geoarchaeology and Radiocarbon Chronology of Stone Age Northeast Asia. Texas A\&M University Press. College Station.

Pitulko V. V., Pavlova E. Y., Ivanova V. V., and Girya E. Y. 2012. The Zhokhov site: geology and stone industry (preliminary report on the excavations of 2000 through 2005). Stratum plus 1: 211-256. (in Russian with English abstract)

Pollmann H.-0. 1999. Obsidian - Bibliographie: Artefakt und Provenienz. Deutsches Bergbau-Museum. Bochum.

Popov V. K., Grebennikov A. V., Kuzmin Y. V., Glascock M. D., Nozdrachev E. A., Budnitsky S. Y., and Vorobey I. E. 2017. Geochemistry of obsidian from Krasnoe Lake on the Chukchi Peninsula (Northeastern Siberia). Doklady Earth Sciences 476: 1099-1104.

Popov V. K., Kuzmin Y. V., Grebennikov A. V., Glascock M. D., Kim J.-C., Oppenheimer C., Budnitskiy S. Y., Hong M.-Y., and Kim J.-Y. 2019. The "puzzle" of the primary obsidian source in the region of Paektusan (China/DPR Korea). Quaternary International 519: 192-199.

https://doi.org/10.1016/j.quaint.2018.12.028

Popov V. K., Sakhno V. G., Kuzmin Y. V., Glascock M. D., and Choi B.-K. 2005. Geochemistry of volcanic glasses of the Paektusan Volcano. Doklady Earth Sciences 403: 254-259.

Rasic J. T. 2016. Archaeological evidence for transport, trade, and exchange in the north American Arctic. In T. M. 
Friesen, O. K. Mason (eds.), The Oxford Handbook of the Prehistoric Arctic. Oxford University Press. New York: 131-152.

Renfrew C. 1975. Trade as action at a distance: questions of integration and communication. In C. Lamberg-Karlovsky (ed.), Ancient Civilization and Trade. University of New Mexico Press. Albuquerque: 3-59.

Sato H., Yakushige M. 2014. Obsidian exploitation and circulation in Late Pleistocene Hokkaido in the northern part of the Japanese Archipelago. In M. Yamada, A. Ono, A. (eds.), Lithic Raw Material Exploitation and Circulation in Prehistory. University of Liege. Liege: 159-177.

Shackley M. S. 2005. Obsidian: Geology and Archaeology in the North American Southwest. University of Arizona Press. Tucson.

Shackley M. S., Glascock M. D., Kuzmin Y. V., and Tabarev A. V. 1996. Geochemical characterization of archaeological obsidian from the Russian Far East: a pilot study. International Association for Obsidian Studies Bulletin 17: 16-19.

Shiba K. 2014. Acquisition and consumption of obsidian in the Upper Palaeolithic on Kyushu, Japan. In M. Yamada, A. Ono, A. (eds.), Lithic Raw Material Exploitation and Circulation in Prehistory. University of Liege. Liege: 205-230.

Shimada K. 2014. Upper Palaeolithic obsidian use in central Japan: the origin of obsidian source exploitation. In M. Yamada, A. Ono, A. (eds.), Lithic Raw Material Exploitation and Circulation in Prehistory. University of Liege. Liege: 179-203.

Shimada K., Yoshida A., Hashizume J., and Ono A. 2017. Human responses to climate change on obsidian source exploitation during the Upper Paleolithic in the Central Highlands, central Japan. Quaternary International 442B: 12-22. https://doi.org/10.1016/j.quaint.2016.07.047

Skinner C. E., Tremaine K. J. 1993. Obsidian: An Interdisciplinary Bibliography. San Jose University. San Jose.

Suda Y. and 15 co-authors. 2018a. Inter-laboratory validation of the WDXRF, EDXRF, ICP-MS, NAA and PGAA ana- lytical techniques and geochemical characterization of obsidian sources in northeast Hokkaido Island, Japan. Journal of Archaeological Science: Reports 17: 379-392. https://doi.org/10.1016/j.jasrep.2017.11.013

Suda Y., Tsuchiya M., Hashizume J., and Oyokawa M. 2018b. Chemical discrimination of obsidian sources in the Kirigamine area and provenance analysis of obsidian artifacts from the Hiroppara prehistoric sites I and II, central Japan. Quaternary International 468: 72-83. https://doi.org/10.1016/j.quaint.2017.11.014

Sugihara S. (ed.) 2014. Occurrence of Obsidian in Japan and its Physical and Chemical Analysis. School of Arts and Letters, Meiji University. Tokyo. (in Japanese with English title)

Tsutsumi T. 2010. Prehistoric procurement of obsidian from sources on Honshu Island (Japan). In Y. V. Kuzmin, M. D. Glascock (eds.), Crossing the Straits: Prehistoric Obsidian Source Exploitation in the North Pacific Rim. British Archaeological Reports IS 2152. Archaeopress. Oxford: $27-55$.

Wada K., Mukai M., Sano K., Izuho M., and Sato H. 2014. Chemical composition of obsidian in Hokkaido Island, northern Japan: the importance of geological and petrological data for source studies. In A. Ono, M. D. Glascock, Y. V. Kuzmin, and Y. Suda (eds.), Methodological Issues for Characterisation and Provenance Studies of Obsidian in Northeast Asia. British Archaeological Reports IS 2620. Archaeopress. Oxford: 67-84.

Wakita K. 2013. Geology and tectonics of Japanese islands: A review - the key to understanding the geology of Asia. Journal of Asian Earth Sciences 72: 75-87. https://doi.org/10.1016/j.jseaes.2012.04.014

Williams-Thorpe 0. 1995. Obsidian in the Mediterranean and Near East: A provenancing success story. Archaeometry 37: 217-248.

https://doi.org/10.1111/j.1475-4754.1995.tb00740.x

Yi S., Jwa Y.-J. 2016. On the provenance of prehistoric obsidian artifacts in South Korea. Quaternary International 392: 37-43. https://doi.org/10.1016/j.quaint.2015.08.012

\section{back to contents}

